\title{
Serum enzyme activities after cardioversion
}

\author{
Tadeusz Mandecki, Leszek Giec, and Włodzimierz Kargul \\ From the Third Medical Clinic, Silesian School of Medicine, Katowice, Poland
}

Serum aspartate aminotransferase (SGOT), alanine aminotransferase (SGPT), creatinine phosphokinase (CPK), and butyric acid dehydrogenase $(B D H)$ were determined in 94 patients before, $I_{2}^{\frac{1}{2}}$ hours, and 24 hours after cardioversion. An increase in SGOT and CPK activity was observed 24 hours after cardioversion in the group of patients treated with two or more DC shocks. The importance of this enzyme activity increase is discussed. It originates in the skeletal muscles and probably has no clinical significance, as no other signs of myocardial damage were observed simultaneously in a large group of patients.

Cardioversion has an established place among the methods of treatment of cardiac arrhythmias. The method is generally safe. However, some complications due to this technique may occur, including systemic emboli, cardiac arrhythmias, and ST and T changes in the electrocardiogram (Åberg and Cullhed, 1968; Lown, 1967; Resnekov and McDonald, 1967, 1968; Sussman, Woldenberg, and Cohen, 1964). Some authors have noted an increase of serum indicatory enzyme activities after cardioversion. This was interpreted as caused either by myocardial or by skeletal muscle damage, or as a phenomenon without any clinical significance. The reports published hitherto have been based on small groups of patients. The aim of the present contribution was to study this phenomenon in a larger group of patients.

\section{Methods and subjects}

The cardioversion was performed using the DC defibrillator (Godart), always under light general barbiturate or Epontil anaesthesia. The energy discharged during the first electroshock was 150 watt sec., and, if necessary, was gradually increased during every subsequent electroshock to 400 watt sec. One electrode was placed under the right clavicle and the other in the left middle axillary line in the fifth intercostal space.

One blood sample for the determination of aspartate (SGOT) and alanine (SGPT) aminotransferases, creatine kinase (CPK), and butyric acid dehydrogenase (BDH) was drawn before cardioversion, the second $\mathrm{I} \frac{1}{2}$ hours, and the third 24 hours after direct-current countershock. Serum activity of aminotransferases was determined according to Reitman and Frankel (1957). The upper normal limit for this method in our labora-

Received 14 January 1970. tory is 30 I.U. The serum activity of CPK was examined by the method of Hughes (1962) (the upper normal limit for men $3.9 \mathrm{U}$., for women 2.7 U.), and serum BDH activity by the method of Rosalki (I962) (upper normal limit I3I U.).

The statistical analysis of the data was made by the paired experiment method (a modification of Student's test) (Oktaba, I966).

A total of 94 patients treated with DC shock were studied. SGOT and SGPT activities were determined in 8I of them, CPK in 59, and BDH in 54. The age of the patients varied between 22 and 73 years. Valvular heart disease was diagnosed in $5 \mathrm{I}$ patients, atherosclerotic heart disease in 38 , lone fibrillation in 4 , and treated thyrotoxicosis in I patient. The reason for cardioversion was atrial fibrillation in 70 cases, atrial flutter in 19, supraventricular paroxysmal tachycardia in 4 , and ventricular paroxysmal tachycardia in I case. Cardioversion restored the normal sinus rhythm in 83 cases, while in II cases it was ineffective.

In order to evaluate the relation between the amount of electrical energy used and the enzyme activity changes, the patients were divided into two groups. Group I, treated with one countershock (Table I), and Group II, those treated with two or more countershocks (Table 2).

\section{Results}

The results are shown in Tables $I$ and 2 . In the first group (Table I) the activity of all four enzymes changed only slightly after cardioversion. In the second group (Table 2) a statistically significant increase in the SGOT $(t=4.85, \quad p<0.0 I)$ and CPK $(t=2.5 I$, $p<0.05)$ activities was observed 24 hours after cardioversion. In spite of this statistical significance, the increase in SGOT activity was not great and often occurred within the normal range. It was higher than the upper limit only in 6 out of 25 patients. The highest SGOT activity in this group of patients was 48 I.U. 
On the other hand, the increase of CPK activity (the highest value $63 \mathrm{U}$.), though less significant, was higher than the upper limit in 8 out of 16 cases (Fig. I).

We have never seen $S T$ and $T$ changes in the electrocardiograms of the patients with increased enzyme activity, though we have observed such changes in other patients treated with cardioversion in our Clinic (Mandecki et al., I969). Neither have we observed any complications in this group, except the transient cardiac rhythm disorders usually encountered after cardioversion, which hardly ever need pharmacological treatment.

\section{Discussion}

Many authors have reported an increase in the muscle enzyme activity after cardioversion (Åberg and Cullhed, I968; Caesar et al., 1969; Castle and Hecht, I964; Hunt and Bailie, I968; Konttinen et al., I969; Reinikainen et al., I965; Slodki et al., 1966; Sussman et al., I964; Turner and Towers, 1965), most often an increase in SGOT and CPK activity. This is also supported by our study. In our subjects the activity of these two enzymes rose only in the group of patients who were treated with two or more DC countershocks. This indicated that a relation existed between these changes and the amount of the electrical energy applied. The other reports on this problem agree (Caesar et al., 1969; Castle and Hecht, I964; Turner and Towers, I965), though some authors did not find this relation (Åberg and Cullhed, I968; Slodki et al., I966).

The lack of complications as well as of electrocardiographic abnormalities in the patients with increased enzyme activity may suggest that the phenomenon we have observed is of no clinical significance. Lown et al. (1962) and Pelěska and Zastava (1966) showed the possibility of morphological and electrocardiographic changes in animals after countershock, especially when alternating current was used. But most authors investigating this problem think that the changes in enzyme activity are not caused by myocardial injury. A case treated with I40 countershocks was reported (Kong and Proudfit, I964), without any myocardial changes caused by electric current at necropsy. The increase in enzyme activity may be due to the enhanced cellular membrane permeability following the action of electric current, and this may facilitate the release of the cellular enzymes into the blood-stream (Slodki et al., I966).

The normal SGPT activity in our patients
TABLE I Patients treated with I DC shock

\begin{tabular}{|c|c|c|c|c|}
\hline \multirow[t]{2}{*}{ Enzyme } & \multirow{2}{*}{$\begin{array}{l}\text { No. of } \\
\text { patients }\end{array}$} & \multicolumn{3}{|c|}{ Enzyme activity (mean values) } \\
\hline & & $\begin{array}{l}\text { Before } \\
\text { cardioversion }\end{array}$ & $\begin{array}{l}I_{2}^{1} \text { hours after } \\
\text { cardioversion }\end{array}$ & $\begin{array}{l}24 \text { hours after } \\
\text { cardioversion }\end{array}$ \\
\hline SGOT & 57 & $17 \cdot 9$ & $\begin{array}{l}18.9 \\
t=0.56 p>0.05\end{array}$ & $\begin{array}{l}19.3 \\
t=0.75 p>0.05\end{array}$ \\
\hline SGPT & 57 & $26 \cdot 9$ & $\begin{array}{l}26.4 \\
t=0.26 p>0.05\end{array}$ & $\begin{array}{l}29.2 \\
t=0.7 \text { I } p>0.05\end{array}$ \\
\hline CPK & 43 & 3.01 & $\begin{array}{l}2.74 \\
t=I \cdot 27 p>0.05\end{array}$ & $\begin{array}{l}2.96 \\
t=0.14 p>0.05\end{array}$ \\
\hline $\mathrm{BDH}$ & 34 & $117 \cdot 9$ & $\begin{array}{l}I 19 . I \\
t=0.12 p>0.05\end{array}$ & $\begin{array}{l}I 16.9 \\
t=0.13 p>0.05\end{array}$ \\
\hline
\end{tabular}

TABLE 2 Patients treated with 2 or more $D C$ shocks

\begin{tabular}{|c|c|c|c|c|}
\hline \multirow[t]{2}{*}{ Enzyme } & \multirow{2}{*}{$\begin{array}{l}\text { No. of } \\
\text { patients }\end{array}$} & \multicolumn{3}{|c|}{ Enzyme activity (mean values) } \\
\hline & & $\begin{array}{l}\text { Before } \\
\text { cardioversion }\end{array}$ & $\begin{array}{l}I_{2}^{\frac{1}{2}} \text { hours after } \\
\text { cardioversion }\end{array}$ & $\begin{array}{l}24 \text { hours after } \\
\text { cardioversion }\end{array}$ \\
\hline SGOT & 25 & I3.8 & $\begin{array}{l}13.4 \\
t=0.3 I p>0.05\end{array}$ & $\begin{array}{l}19.8 \\
t=4.85 p>0.0 I\end{array}$ \\
\hline SGPT & 25 & $I 6 \cdot 8$ & $\begin{array}{l}I 4.7 \\
t=I \cdot 29 p>0.05\end{array}$ & $\begin{array}{l}I 8.3 \\
t=0.60 p>0.05\end{array}$ \\
\hline CPK & I6 & $2 \cdot 17$ & $\begin{array}{l}2.20 \\
t=0.32 \quad n>0.05\end{array}$ & II 65 \\
\hline $\mathrm{BDH}$ & 20 & $97 \cdot 0$ & $\begin{array}{l}t=0.32 p>0.05 \\
I 0 I .8 \\
t=0.58 p>0.05\end{array}$ & $\begin{array}{l}\tau=2.51 p<0.05 \\
88.2 \\
t=0.97 p>0.05\end{array}$ \\
\hline
\end{tabular}

FIG. Serum CPK after cardioversion (the patients with two or more $D C$ shocks).

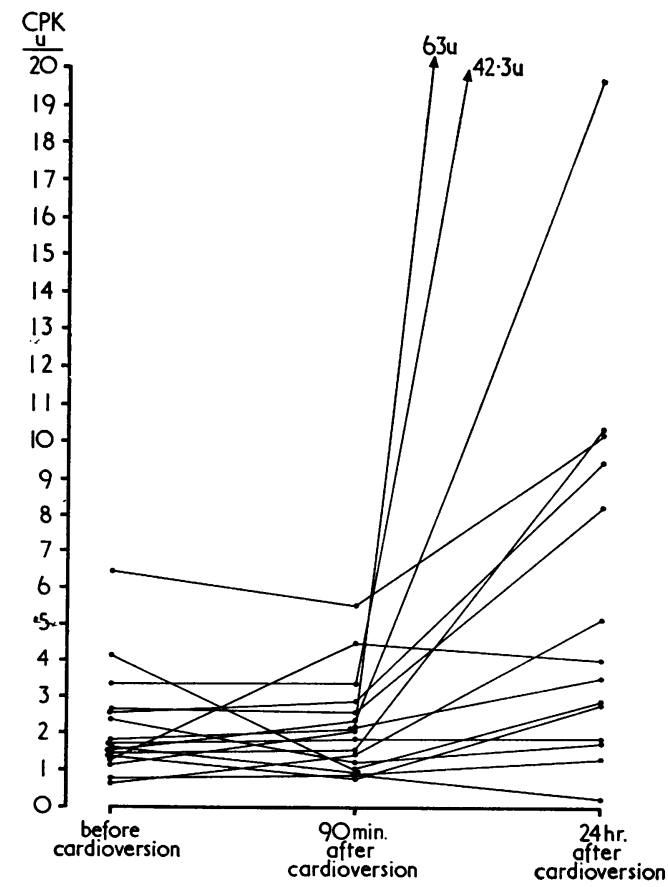


seems to exclude the liver as the source of other altered enzyme activities. The most probable source of the increased SGOT and CPK activity is skeletal muscles, where these two enzymes are abundantly present. Other authors are of the same opinion (Caesar et al., 1969; Hunt and Bailie, 1968; Konttinen et al., 1969). Recently, Konttinen et al. (1969), in their study on LDH isoenzyme activity after cardioversion, excluded the myocardium as the enzyme-releasing tissue. Slodki et al. (I966) reported that aldolase, known to indicate skeletal muscle damage (Hughes, 1962), increased more sensitively than SGOT after DC shock. Raised serum CPK activity does not necessarily indicate necrosis, since muscular exercise (Griffiths, 1965) and also appendectomy (Hunt and Bailie, 1968) can increase serum CPK activity. An increased tissue permeability evoked by hyperaemia (the thermoelectric effect) or contractions of thoracic muscles may cause the release of enzymes into the serum after cardioversion (Konttinen et al., 1969).

We wish to express our thanks to Prof. Dr. med. Kornel Gibinski for encouragement and helpful advice. Miss Jadwiga Kubisa of the Department of Electrocardiography gave valuable assistance.

\section{References}

Åberg, H., and Cullhed, I. (1968). Direct current countershock complications. Acta Medica Scandinavica, 183, 415 .

Caesar, K., Knodel, W., Jeschke, D., and Schollmeyer, P. (1969). Serumenzyme nach Elektroregularisierung von Herzrhythmusstörungen. Medizinische Klinik, 64, 70.

Castle, C. H., and Hecht, H. H. (1964). Evaluation of adverse effects on the heart of direct current shocks to the intact chest (Abstract). Clinical Research, 12, 77.

Griffiths, P. D. (1965). Serum creatine kinase and exercise. British Medical fournal, 2, 167.

Hughes, B. P. (1962). A method for the estimation of serum creatine kinase and its use in comparing creatine kinase and aldolase activity in normal and pathological sera. Clinica Chimica Acta, 7, 597.

Hunt, D., and Bailie, M. J. (1968). Enzyme changes following direct current countershock. American Heart fournal, 76, 340.
Kong, T. Q., and Proudfit, W. L. (1964). Repeated direct-current countershock without myocardial injury. Fournal of the American Medical Association, 187, 60.

Konttinen, A., Hupli, V., Louhija, A., and Härtel, G. (1969). Origin of elevated serum enzyme activities after direct-current countershock. New England fournal of Medicine, 281, 231.

Lown, B. (1967). Electrical reversion of cardiac arrhythmias. British Heart fournal, 29, 469.

- - Neuman, J., Amarasingham, R., and Berkovits, B. V. (1962). Comparison of alternating current with direct current electroshock across the closed chest. American fournal of Cardiology, 10, 223.

Mandecki, T., Giec, L., Dosiak, J., Trusz, M., and Dyaczyńska, A. (1969). Cardioversion in atrial flutter and fibrillation. (In Polish; English summary.) Polskie Archiwum Medycyny Wewnętrznej, 43, 1259.

Oktaba, W. (1966). Elementy statystyki matematycznej $i$ metodyka doświadczalnictwa. P.W.N., Warsaw.

Pelěska, B., and Zastava, V. (1966). Der heutige Stand unserer Erkenntnisse über der Elektrotherapie der Herzarrhythmien. 5. Frieb. Colloqium 1965. WerkVerlag, München-Gräfelfing.

Reinikainen, M., Koskinen, P., Pöntinen, P., and Siitonen, L. (1965). Experiences in the use of direct current countershock in the treatment of cardiac arrhythmias. Acta Medica Scandinavica, 178, Suppl. 437.

Reitman, S., and Frankel, S. (1957). A colorimetric method for determination of serum glutamic oxalacetic and glutamic pyruvic transaminases. American fournal of Clinical Pathology, 28, 56.

Resnekov, L., and McDonald, L. (1967). Complications in 220 patients with cardiac dysrhythmias treated by phased direct current shock, and indications for electroconversion. British Heart fournal, 29, 926.

$\longrightarrow$, and - (1968). Appraisal of electroconversion in treatment of cardiac dysrhythmias. British Heart fournal, 30, 786.

Rosalki, S. B. (1962). A simple colorimetric method for the determination of serum alpha-hydroxybutyric dehydrogenase activity. Fournal of Clinical Pathology, 15, 566.

Slodki, S. J., Falicov, R. E., Katz, M. J., West, M., and Zimmerman, H. F. (I966). Serum enzyme changes following external direct current shock therapy for cardiac arrhythmias. American fournal of Cardiology, 17, 792.

Sussman, R. M., Woldenberg, D. H., and Cohen, $M$. (1964). Myocardial changes after direct current electroshock. Fournal of the American Medical Association, 189, 739.

Turner, J. R. B., and Towers, J. R. W. (1965). Complications of cardioversion. Lancet, 2, 612. 